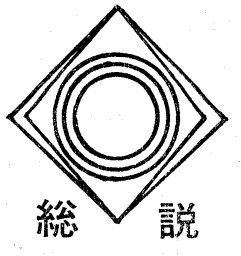

\section{都市ごみ処理に際して得られる \\ エネルギーの利用}

国士館大学 山田衛

\section{1.はじめに}

昭和48年の中東戦争, 続いて昨年来のイラン政変を きっかけに, 石油の確保が困難になった。代替エネル ギー源として, 原子力高速増殖炉, 石炭ガス化液化, 地熱, 潮力, 温度差発電, 太陽熱利用, バイオマス利 用, 水素然料化など多くの研究開発プロジェクトが進 められ，ポスト石油を真剣に考学るよらになってきて いる。しかるに，いずれのテーマも開発には長期間の 年月を必要とし, 今すぐ石淊に代るには余りにも現在 の経済社会に及涩す石油の占有率が高く, 量的はもち ろん, 経済的, 技術的にも程遠い感がある。代替エネ ルギーの開発は重要政策に間違いないが，目星のつく まで石油消費を節減する省エネルギーが, 現在社会の 最優先施策であると考える。この意味に就いて, 熱量 としては微々たるものではあるが，ごふの持つェネル ギーを活用することは，既存技術だけで十分対処でき る速效性省エネルボー策のひとつとして意義がある。 しかるに,ごみ熱利用の現状は, 数多いごみ処理施設 の中で熱利用を行っている施設は僅かしかなく, 蓺を 利用している施設にあってもとの熱利用率は $3 \sim 4 \%$ にしかすぎい。ようやく最近に至って 8 〜 9\%の焼 却施設が建設されるよらになったが，新鋭火力発電所 の40\%強に比べるとあ屯りにも低率である。この点に 着目し, 積極熱利用方策として

(1)現有システムを変更することなく熱利用率を高める 方法はないか。

(2)システムを変更すれば有利となるか。

(3)他のエネルギー発生源設備とカップルした場合の熱 利用率はどらなるか。

(4)別の処理施設と僧合して相互利用した場合の総合熱 バランスは如何に。

以上の方策について, 熱利用用途面で汎用性の高い発 電利用を中心に数值的考察をこころみることにした。

本会可燃性廃棄物委員会委員

干238 横須賀市汐入町3-14（自宅）
ただし，下記試算は外乱を考慮しない理論值に近い 条件設定を行っているので，留意顧いたい。

\section{2. 条件設定を变更した場合のごみ焼却発電}

わが国のごみ焼却発電は昭和 40 年に竣工した大阪市 西淀川工場 ( $3,375 \mathrm{kVA})$ を最初とし，今までに約 40 工場建設されている。発電施設を持つ焼却施設能力規 模は，1施設当り平均 $730 \mathrm{t} /$ 日（1基当り $260 \mathrm{t} /$ 日） であって大容量に属す規模施設に限定されていた。第 1 次オイルショックを境として自家発電設備を備えた 施設の建設が目立つようになってきたが，昨年の中東 紛争から原油価格高騰期を迎えて, 維持費節減, いわ ゆる省エネルギーに本腰を入れざるを得なくなった。 先般東京都と東京電力とが売電料金值上げ（4月に逆 上って約60\%）について締結したことも，各自治体の 発電に対する見直しと積極化を促し，補助金項目認 可, 小形タービンの開発も相まって, 従来中規模程度 以上しか行われなかった自家発電は，小規模燒却施設 にまで急速にその輪を広げる気運になっている。

焼却するのに重油の助然が必要であったことは今や 昔の物語り，ごみ質が好転して，ごみ焼却施設はェネ ルギー過剩施設となり，電力の自給自足はもとより， 系外にぬで電力その他エネルギーを送り出すことが国 家的見地から重要になってきた。しかるに，既設の発 電設備保有施設のらち, 発生余剰電力を逆送電してい る施設は数工場を数えるしかない。最近，中小規模施 設の発電設備を折込んだ計画を耳にするようになって きれ。次の時代には，ごみも燃料なりとの思想でごみ の潜在エネルギーを可能な限り引出す方策が講じられ るようになるに相違ない。定着したごみ焼却技術の殼 を破りシステムを変更する際の困難さは予想でき, 一 朝一夕には改善されないと思われるが，着実にステッ プを踏んで実現されることが望まれる。

この意味に乱いて, 在来燒却システムの条件設定を 変更してぞの程度熱利用率が変るかを検討するのも無 意義ではない。次項に 5 つの条件設定とそれらの組合 せを行った。比較の外乱を避けるために, 計算は理論 


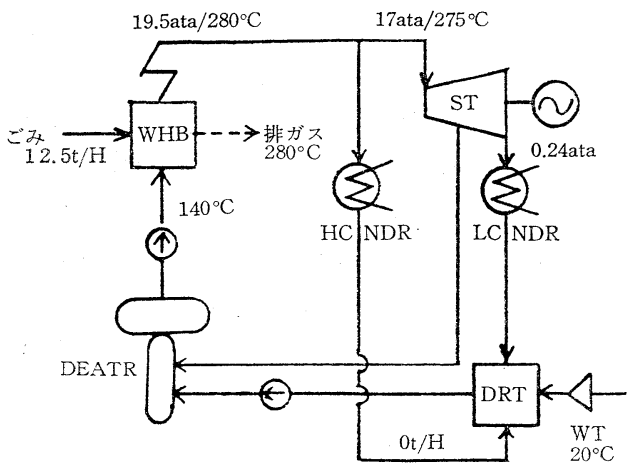

WHB : 焼却帄廃熱ボイラー

$\mathrm{ST}:$ 蒸気タービン

DRT : 復水タンク

DEATR : 脱気器

HCNDR : 高压復水器

LCNDR : 低圧復水器

WT: 純水装置

图 1 ベース条件フロー

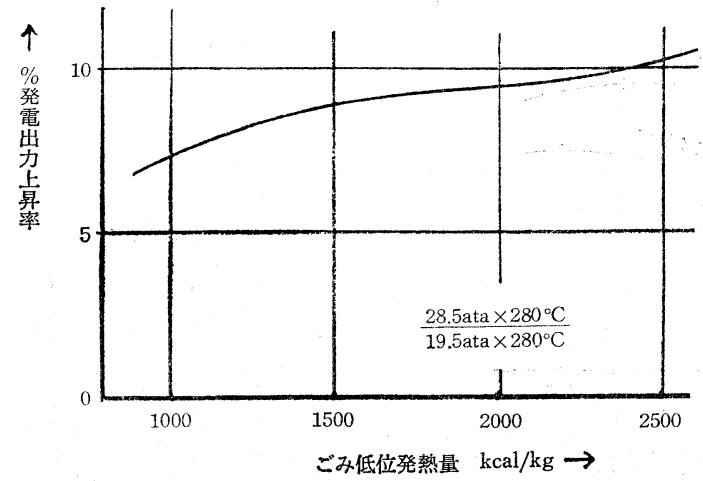

图 2 蒸気压力による出力上界率

值に近く些細な損失や，系内消費余熱利用学よび負荷 変動に対する流量カットなど考慮していない。それ故 実祭の採用可能值は或程度割引いて考えなければいけ ない。また, 痓却絶対量大小による各種效率の変動值 も見达んでいない。

比較対象とした計算ベース条件は, 既存施設中最高 と思われる某施設を選んだ。概略フローは図1 の通り で，条件数値 ${ }^{1)}$ を図示した。

2.1 ケース1 (ボイラー正力をアップさせた場合) 単位流量当りの蒸気でタービンの仕事量増大策とし て先ず考えられる条件は, 蒸気温度の高温化である が，残念ながらごみ焼却排ガスによる高温腐食対策を 解決しない限り, 高温化は望めない。腐食発生温度 は, 著名な V.K.Fäßler の研究によって, 金属温度 $320^{\circ} \mathrm{C}$ より起きることになっている。これを肯定する そ $320-50=280^{\circ} \mathrm{C}$ の蒸気温度はざりぎりの上限值と考 党られる。それ故, 燒却方式に和ける能力アップ策と して採用しない。

蒸気圧打を上げても出力アップには蒸気温度程の寄 与率にならないが, 次の 2 点から若干発電出力を増す
傾向を示す。これをケース 1 とした。

(1) ボイラー発生蒸気エンタルピは同一蒸気温度の 場合圧力の高い程若干少く, 蒸発量が増す。

(2) 蒸気 H-S 線図の比エントロピ位置が後退して タービンの断熱熱落差が大きくなる。

飽和蒸気管の高温腐食が，過熱器と同様の理由からお きると仮定すると，蒸気圧力は 100 ata 程度まで上げ てもよいが，温度とのバランスがとれないし，耐圧部 構造上不経済である。耐圧規格を従来のフランジ圧力 より 1 ランクあげた $30 \mathrm{~kg} / \mathrm{cm}^{2} \cdot \mathrm{g}$ とし, 過熱器出口压 力を 28.5 ata に設定した。ベース条件である 19.5 ata とは図 2 の通り各ごみ低位発熱量に対し, 発電出力上 昇率 $\div 8 \sim 10 \%$ 好転する。

2.2 ケース 2 (空冷復水器真空王力を下げた場合)

ごみ焼却施設の建設地が臨海地域ならば, タービン 排気を海水冷却として火力発電所同等の復水器真空圧 を得ることもできよらが，通常，内陸の辺境地に建設 され，空気冷却方式を主に用いている。外国に例を多 く見るクーリングタワー方式は，なぜかわが国では敬 遠されている。復水タービンの排気圧力は外気温度の 


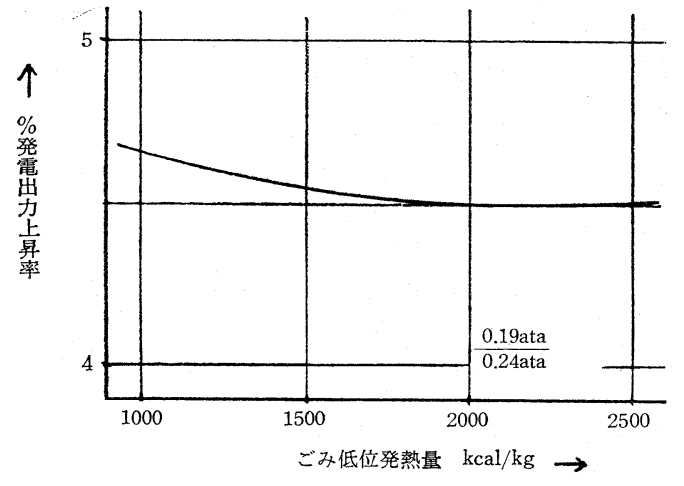

図 3 タービン排気圧力による出力上昇率

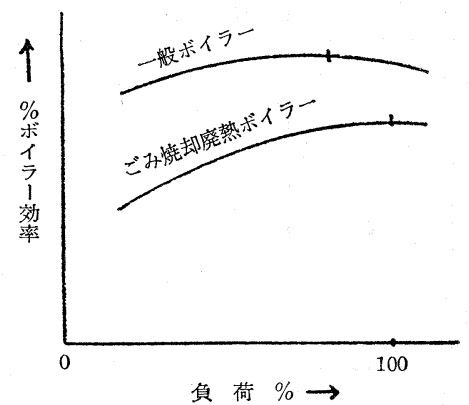

図 4 ボイラー効率曲線

採り方で決定される。気温と蒸気量は季節変動する性 格があり, 復水器の冷却負荷は一定でない。普通マル チュニット式の強制空冷式が設置され, 稼動ユニット 数を調節することによって所要冷却負荷に合せる運転 方法が採られている。また, 冷却負荷はごみ最高発熱 量時を設計点とするが, 最高ごみ質は将来の予測值で あって常用負荷は遙かに低い。その上外気温度は年間 $1 \sim 2$ 回, 連続 $1 \sim 2$ 時間しか続かない真夏の最高気 温をべースに伝熱面積の決定がなされるので, 設備の 年間稼動率は非常に悪い。復水器にとって最悪の条件 が重なった時, 負荷を下げる予定にすれば復水器を小 さくできるし，真空圧力も在来の圧力より下げること ができよう。この考光方からすれば0.19 ata は十分可 能な值である。ベース条件の 0.24 ata は従来の条件よ り相当進歩した值であって，0.24から0.19 ata に下げ ても発電出力上昇率は $4.5 \%$ 前後にしかならず，それ 程目立った方策に見えないが, 過剩設備の縮小も立派 な省エネルギー対策である。

2.3 ケース 3 (燃焼排ガス温度を下げた場合)

燃燒炉の廃熱ボイラーは, 一般産業ボイラーのよう にボイラー効率を重視した設計でなく, 安定操業を第
一義化考光ている。それ故，効率は低く70\%を越光る ことはない。熱利用率を重点思考するならばまずボ イラー効率を上げなければならない。熱損失の中で一 番大きい排ガス損失を少なくするためには，排ガス温 度を下げればよいが，このような実績は今までにな い。焼却炉廃熱ボイラーの出口温度制限は, 上限にあ って下限はないに等しい。上限温度は普通鋼材保護 と, $\mathrm{E} / \mathrm{P}$ 電極へのダスト固着, 特よび $\mathrm{ZnSO}_{4}, \mathrm{ZnCl}_{2}$ など金属塩による高温腐食防止のため， $350^{\circ} \mathrm{C}$ 以下(設 計最高許容温度）普通 $280 \sim 290^{\circ} \mathrm{C}$ が選定される。下限 温度は低温腐食の起きない温度, とだけしか特に定説 はない。低温腐食は露点温度飞等しい。露点温度は $\mathrm{HCl}$ ガスが $65^{\circ} \mathrm{C}$ 前後であるけれども, 若干の $\mathrm{SO}_{2}$, $\mathrm{SO}_{3}$ ガスも混在するので $150^{\circ} \mathrm{C}$ を許容下限温度として よいであ万う。しかし, 給水温度との温度差が少ない と，エコノマイザ伝熱面積が大きくなって不経済であ る。200总以下にはしたくない。それ故，220学を下限 温度に設定した。

ごみ焼却廃熱ボイラーには，産業用ボイラーに見ら れないボイラーまたはエコノマイザガスバイパスと称 する特異な装置があって，出口ガス温度を一定になる よう通過ガス量を調節する。なぜ一定にさせるのか理 由は判然としない。低負荷では飽和温度と排ガス温度 の温度差が縮まるため，吸収熱量が少なくなって或程 度自然に温度調節が行われる。しかるに，バイパスを 開いて熱吸収量をさらに減少させる操作を行らので, 低負荷に括ける効率ダウンは一般ボイラーのそれより 激しい。図4 亿ボイラー効率曲線の傾向を示した。京 た，ボイラー効率の最良点は，一般ボイラーが定格負 荷の注ほ80\%付近の負荷（経済負荷）に求められるが， 焼却廃熱ボイラーは最大入熱時（最高発熱量 $\times$ 定格負 荷）が設計基準点になるので，図のように効率の最良 点は一般ボイラーより高負荷側にづれている。以上を 加算すると廃熱ボイラーの平常稼動時（図の低負荷に 相当) のボイラー効率は想像以上飞低い。建設当初か ら何年先に訪れるかわからない定格負荷を設計基準点 飞定めるのではなく，たと党ば，エコノマイザ加熱管 を壇設可能構造にした設備に止め, 常時高効率で稼動 できる配慮が望ましい。この方策も省エネルギー策で ある。負荷変動は計算に表われない。この試算では単 に定格負荷時の比較になる。排ガス温度を $280^{\circ} \mathrm{C}$ から $220^{\circ} \mathrm{C}$ に下げることによって，図5 の通りボイラー効 率は約 $9.1 \%$ 前後, 発電出力の上昇率は約 $9.7 \sim 9.3 \%$ であった。

2.4 ケース 4 


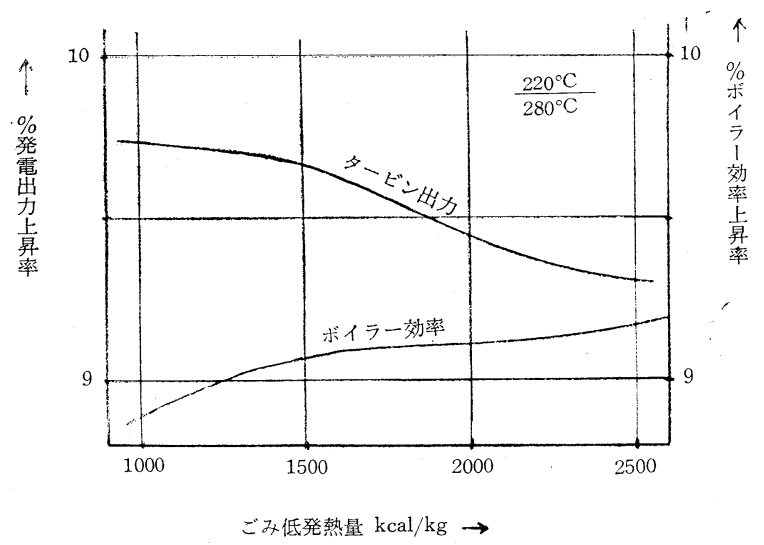

图 5 排ガス温度ダウンによる影響

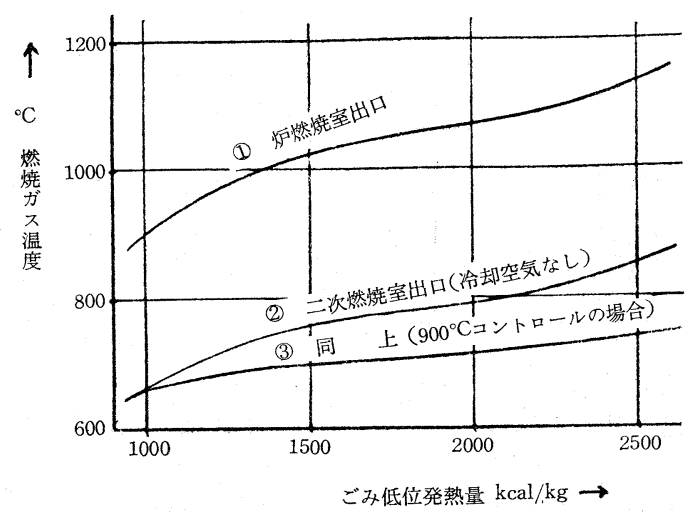

図 6 廃熱ボイラー燃焼室出ロガス温度

（燃焼室出口ガス温度制限を撤廃した場合）

ごみ焼却炉運転操作上の目安として, 燃焼室出口ガ ス温度の監視がある。構造指針にも700 950 $\mathrm{C}$ に操作 するよう義務づけられている。最近のごみ質は，燃焼 して $700^{\circ} \mathrm{C}$ 以下のガス温度になることはまず考えられ ない。反対に $1000^{\circ} \mathrm{Cを}$ 越す場合の方が多い。燃焼温度 はごみ発熱量と空気温度および過剩空気率によって計 算上求められる。図 6 (1) (ベース計算値)に見られる ように，日常運転では制限温度以上になっていること の方が多い。950 $\mathrm{C}$ を越えると（制限温度 $=900^{\circ} \mathrm{C}$ に指 定される場合も多(), 冷空気を燃焼室出口付近や, ストーカ下部より送入して制限温度までュントロール する。そもそもこの上限温度制限設定は, 飛灰の軟化 や溶融によるダストトラブルを防止する目的から定め られたものであるが, 最近は加えて Thermal NOx 抑 制の意味をも含まれている。前者のダストトラブルに ついては，構造指針に「燃焼室下部まで水冷壁を有す る施設にあっては，この限りではない。」とうたわれ， $950^{\circ} \mathrm{C}$ の制限温度を外されているように，習慣的にな っている冷空気送入はこの際止めるべきである。必要 としない裏付けとして図 6 を用意した。バードネスト のよらなダストトラブルが起きる可能性のある場所は 接触伝熱管群入口である。ボイラーの構造によりその 位置は相違するが，二次燃焼室とも呼ばれる放射水冷 壁で囲まれたボイラー火炉出口を制限温度以内にキー プすればよい。筆者の計算によると, $80 \mathrm{~m}^{2} の$ 放射伝熱 面積を持つ150t/日の廃熱ボイラーにおいて, 火炉出 ロガス温度は図 6 (2)の如く, 冷却用泠空気送入を行わ なくとも $900^{\circ} \mathrm{C}$ に達しない。(3) $900^{\circ} \mathrm{C}$ 制限した場 合の火炉出口温度)

後者の NOx 抑制については2 3の研究論文 ${ }^{2) 3)}$ が発 表されている。焼却炉の NOx 発生主因は Fuel NOx であって, Thermal NOx は比較的少ないため, 冷空 気を燃焼室出口に送入しても希瀵効果しかない。ス卜 一力下部送入万式は, 見掛上の効果はあるが, $\mathrm{O}_{2}=12$ \%換算 $\mathrm{NOx}$ は， $\mathrm{O}_{2}$ 一定のときりニアとなり， 入熱 


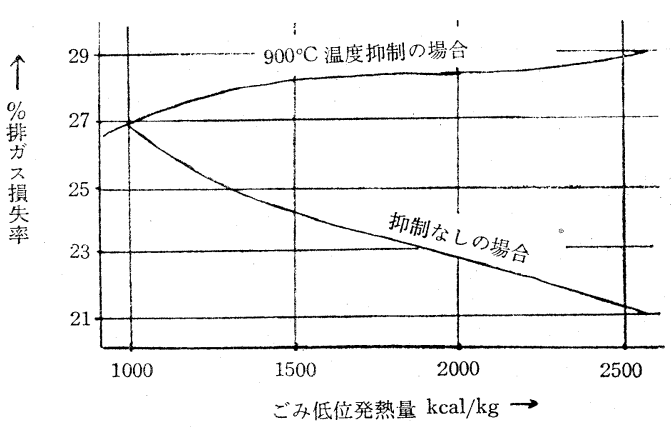

図 7 ガス温度抑制による排ガス損失率

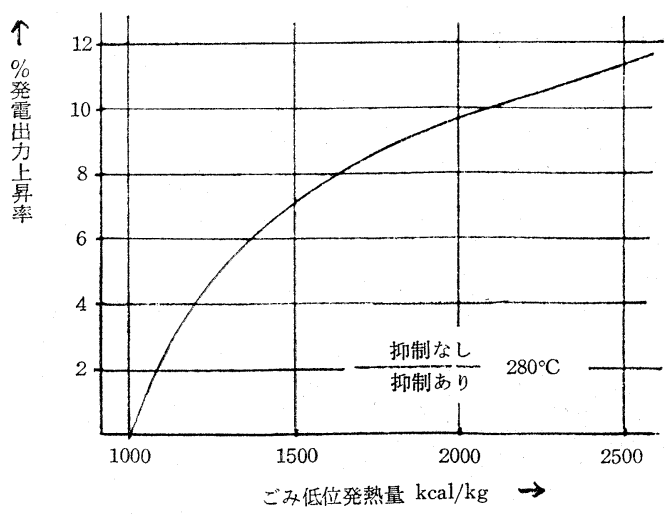

図 8 ガス温度抑制による出力上昇率

一定ならば $\mathrm{O}_{2} \%$ に正比例する関係が明らかにされて いて，実質上の成果は得られない。しかし，逆焰炉の 乾燥ゾーンより,ごみの一部が乾留され, $\mathrm{NH}_{3}, \mathrm{HCN}$, CO などの還元ガスが発生する。また，発生 NOx を 還元させる目的から，乾燥ス卜一カ部送入空気を不足 気味にして $\mathrm{NH}_{3}$ を発生させる運転操作方法も西っ て，これら還元ガスの酸化工程のために，若干の高圧 二次空気をガス流中に攪乱用として吹込む必要がある が，その量と圧力怙よび炉形状なぞ今後の研究により 決定されなければならないテーマである。

以上述べたよらに，廃熱ボイラー付の場合には 900 $\sim 950^{\circ} \mathrm{C}$ 亿温度抑制する必要は認められない。冷空気 送入を行わないと，当然ボイラー通過ガス量は大幅に 減りその結果次のメリットが生ずる。

(1) 損ガス損失は発熱量上位程減少し，その分だけ ボイラー効率が上昇する。

(2) ボイラー本体（伝熱面積）打よび煙道補機の容 量が小形汇なり，設備費の軽減，維持費節減汇効 果がある。

(3) 水冷壁放射部単位面積当りの熱吸収量は増加

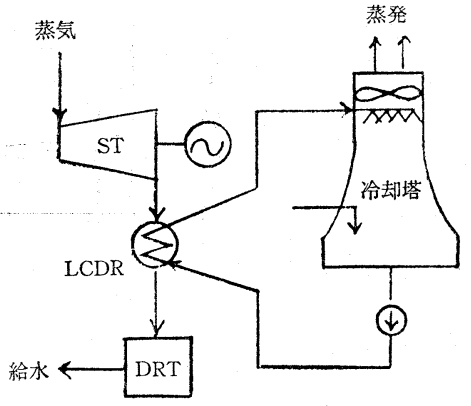

図 9 水冷却復水方式

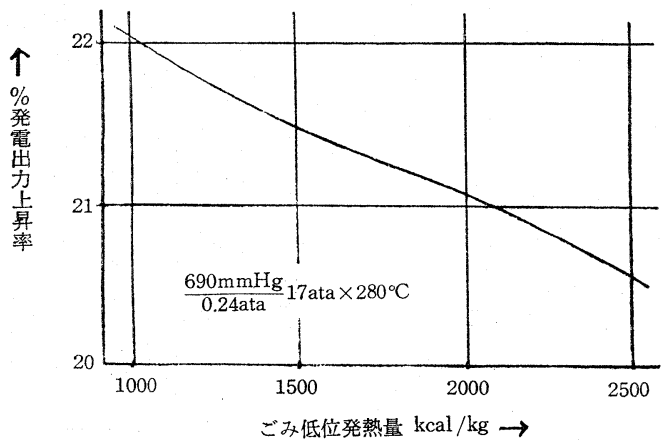

図 10 水冷-空冷出力差

し，構造上の軽量化が可能となる。

図 7 は $900^{\circ} \mathrm{C}$ に燃焼室出口ガス温度を冷却した場合 と, 温度制御しなかった時との排ガス損失率の相違を 表わした図で，約 $1,000 \mathrm{kcal} / \mathrm{kg}$ を基点として発熱量 が高くなる程損失率のひらきは大きくなる。排ガス損 失が少なくなれば当然ボイラー効率は好転し, 蒸発量 増加に伴って，図 8 のように発電出力は増大し, $\mathrm{Hl}=$ $2,000 \mathrm{kcal} / \mathrm{kg}$ 飞拈いて約 $10 \%$ の出力上昇が期待でき る。なお，図中の $280^{\circ} \mathrm{C}$ とはベース条件の排ガス温度 を示す。

2.5 ケース 5 (水冷式復水器を採用した場合)

前述2.1〜2.4亿揭げた各ケースは，既存現有システ ムをできるだけ変更せずに発電出力を引出せる方法に ついて検討してきたが，累積効果はあったとしても， ケース毎の成果は差程大きくない。蒸気タービンにお いて，単位流量当りの蒸気により大きい仕事量をさせ るには，断熱熱落差を大きく採れる蒸気条件を設定す ることである。タービン入口側は過熱蒸気温度を $280^{\circ} \mathrm{C}$ 以上に設定できないとすれば高エンタルピを望めな い。出口側は復水器の真空圧力によって決定されるの で要るから，冷却方式が空気冷却ならばケース 2 が限 界と思われる。とすればこれ以上を求めるには，シス 
表 1 比較試算指数総括表

(指数単位: \%)

\begin{tabular}{lcccccccc}
\hline & ベース值 & ケース & ケース & ケース & ケース & ケース 5 & 総 & 合 \\
\hline ボイラー効率 & 100 & 100 & 100 & 109.05 & 108.08 & 100 & 115.45 \\
蒸 & 発 量 & 100 & 101.34 & 100 & 109.05 & 108.09 & 100 & 115.45 \\
発電端出力 & 100 & 109.46 & 104.5 & 109.44 & 108.44 & 121.03 & 151.16 \\
\hline
\end{tabular}

〈備考〉 1. 指数とはベース計算值を 100 とした時の各項目毎の\%

2. ベース値は $\mathrm{S} / \mathrm{H}$ 出口 $19.5 \mathrm{ata} / 280^{\circ} \mathrm{C}$, タービン入口 $17 \mathrm{ata} / 275^{\circ} \mathrm{C}$, 復水器圧 $0.24 \mathrm{ata}$, 排ガ ス温度 $=280^{\circ} \mathrm{C}$ の時の值

3. ケース 1 は, S/H 出口圧力 $=28.5 \mathrm{ata}$, タービン入口圧力 $=26$ ata に変更した場合の計算值

4. ケース 2 は, 復水器内圧力を 0.19 ata にした時の計算值

5. ケース 3 は, 排ガス温度を $220^{\circ} \mathrm{C}$ に下げた時の計算值

6. ケース 4 は, 燃焼室出ロガス温度制限を撤廃した時の計算值

7.ケース 5 は, 復水器冷却を水冷にした時の計算值

8. 総合とは, ベース值に，ケース $1 〜 5$ 全部を折込んだ時の計算值

9. ずベての計算は, $\mathrm{H} l=2,000 \mathrm{kcal} / \mathrm{kg} \times 12,500 \mathrm{~kg} / \mathrm{H}$ の時の計算值

表 2 発電 端 熱効 率

(単位: \%)

\begin{tabular}{|c|c|c|c|c|c|c|c|}
\hline \multirow{2}{*}{ 冷 却 空 気 } & 排ガス温度 & 復水器圧 & タービン入口压力 & & 発 & 量 & $\mathrm{kcal} / \mathrm{kg}$ \\
\hline & ${ }^{\circ} \mathrm{C}$ & $\overbrace{(\mathrm{mmHg})}^{\mathrm{ata}}$ & ata & 1,000 & 1,500 & 2,000 & 2,500 \\
\hline \multirow{6}{*}{ 然焼室出口温度制限あり } & \multirow{4}{*}{280} & 0.24 & $\begin{array}{l}17 \\
26\end{array}$ & $\begin{array}{l}12.29 \\
13.22\end{array}$ & $\begin{array}{l}13.12 \\
14.3\end{array}$ & $\begin{array}{l}13.41 \\
14.68\end{array}$ & $\begin{array}{l}13.57 \\
14.97\end{array}$ \\
\hline & & 0.19 & $\begin{array}{l}17 \\
26\end{array}$ & $\begin{array}{l}12.86 \\
13.66\end{array}$ & $\begin{array}{l}13.71 \\
14.74\end{array}$ & $\begin{array}{l}14.01 \\
15.12\end{array}$ & $\begin{array}{l}14.22 \\
15.44\end{array}$ \\
\hline & & (690) & $\begin{array}{l}17 \\
26\end{array}$ & $\begin{array}{l}15 . \\
15.61\end{array}$ & $\begin{array}{l}15.93 \\
17.02\end{array}$ & $\begin{array}{l}16.23 \\
17.4\end{array}$ & $\begin{array}{l}16.47 \\
17.74\end{array}$ \\
\hline & & 0.24 & $\begin{array}{l}17 \\
26\end{array}$ & $\begin{array}{l}13.49 \\
14.59\end{array}$ & $\begin{array}{l}14.38 \\
15.72\end{array}$ & $\begin{array}{l}14.68 \\
16.12\end{array}$ & $\begin{array}{l}14.94 \\
16.44\end{array}$ \\
\hline & \multirow[t]{2}{*}{220} & 0.19 & $\begin{array}{l}17 \\
26\end{array}$ & $\begin{array}{l}14.11 \\
15.05\end{array}$ & $\begin{array}{l}15.04 \\
16.20\end{array}$ & $\begin{array}{l}15.35 \\
16.53\end{array}$ & $\begin{array}{l}15.60 \\
16.92\end{array}$ \\
\hline & & (690) & $\begin{array}{l}17 \\
26\end{array}$ & $\begin{array}{l}16.47 \\
17.42\end{array}$ & $\begin{array}{l}17.48 \\
18.67\end{array}$ & $\begin{array}{l}17.77 \\
19.12\end{array}$ & $\begin{array}{l}18.06 \\
19.43\end{array}$ \\
\hline \multirow{6}{*}{ 燃焼室出口温度制限なし } & \multirow{3}{*}{280} & 0.24 & $\begin{array}{l}17 \\
26\end{array}$ & $\begin{array}{l}12.31 \\
13.25\end{array}$ & $\begin{array}{l}14.07 \\
15.39\end{array}$ & $\begin{array}{l}14.54 \\
15.96\end{array}$ & $\begin{array}{l}\text { 15. } 21 \\
16.74\end{array}$ \\
\hline & & 0.19 & $\begin{array}{l}17 \\
26\end{array}$ & $\begin{array}{l}12.88 \\
13.68\end{array}$ & $\begin{array}{l}14.72 \\
15.86\end{array}$ & $\begin{array}{l}15.19 \\
16.44\end{array}$ & $\begin{array}{l}15.89 \\
17.24\end{array}$ \\
\hline & & (690) & $\begin{array}{l}17 \\
26\end{array}$ & $\begin{array}{l}15.02 \\
15.84\end{array}$ & $\begin{array}{l}17.12 \\
18.28\end{array}$ & $\begin{array}{l}17.61 \\
18.92\end{array}$ & $\begin{array}{l}18.39 \\
19.81\end{array}$ \\
\hline & \multirow{3}{*}{220} & 0.24 & $\begin{array}{l}17 \\
26\end{array}$ & $\begin{array}{l}13.50 \\
14.60\end{array}$ & $\begin{array}{l}15.15 \\
16.56\end{array}$ & $\begin{array}{l}15.59 \\
17.22\end{array}$ & $\begin{array}{l}16.16 \\
17.84\end{array}$ \\
\hline & & 0.19 & $\begin{array}{l}17 \\
26\end{array}$ & $\begin{array}{l}14.13 \\
15.06\end{array}$ & $\begin{array}{l}15.84 \\
17.10\end{array}$ & $\begin{array}{l}16.29 \\
17.64\end{array}$ & $\begin{array}{l}16.82 \\
18.52\end{array}$ \\
\hline & & $(690)$ & $\begin{array}{l}17 \\
26\end{array}$ & $\begin{array}{l}16.49 \\
17.44\end{array}$ & $\begin{array}{l}18.38 \\
19.66\end{array}$ & $\begin{array}{l}18.88 \\
20.27\end{array}$ & $\begin{array}{l}19.55 \\
21.05\end{array}$ \\
\hline
\end{tabular}

テム変更をせざるを得ない。すなわち，空冷方式から 水冷方式への転换である。火力発電所の海水冷却設備 のよらな方法を採用しなくとも，クーリングタワー方 式にすれば内陸地に叔いても水冷方式を採用すること
ができ，高い真空圧力を得ることが可能である。ク一 リングタワーは, 蒸発水を大気に放散させるため, 比 較的多量の用水消費を伴らが，水利の地であれば検討 に值する魅力ある方式である。(1)空冷式より設備費低 


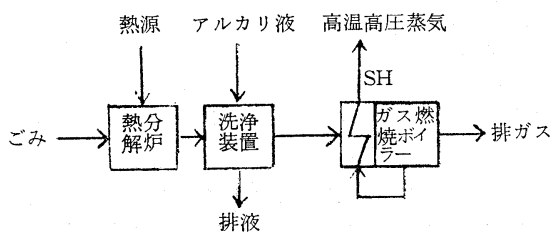

図 11 熱分解方式ブロックシート

廉, (2)設置面積小, (3)小規模焼却炉の発電設備設置可 能, 復水器真空圧力は $690 \mathrm{mmHg}$ 程度まで下げるこ とができる。(0.24 ata=約 $560 \mathrm{mmHg})$ この真空圧力 をべース条件に適用させると, 図10の通りとなって, 発電出力は一挙に〜21\%～增強できる。

\section{6 総 括}

ごみ燒却発電設備の発電出力増強策を縓めると表 1 に示す計算結果になった。いずれの策も現在使用され ている技術の枠を，大きく逸脱することなく採用する ことができる。ッース 5 のクーリングタワー方式も， 有害ガス湿式洗浄設備の凝縮塔に用いられている設備 であって，目新しい技術ではない。

ベースに採用した条件は, 蒸気温度, 排ガス温度, タービン排圧，いずれも従来の施設の条件に比べると 現存する最高の出力を期待できる。ケース 1 から 4 ま ですべてを加味すると， $\mathrm{Hl}=2,000 \mathrm{kcal} / \mathrm{kg}$ のとき， そのベース施設の出力ょり約 $31.5 \%$ 発電出力アップと なり, さらに, 復水器を水冷に変えると実に $50 \%$ 以上 も多くの電力を得ることができる。

ごみェネルギーの電気エネルギー転換方式の最終効 果達成度は, 発電端熱効率（†熱利用効率とする）の 比較値で見るべきであ万う。表 2 は設定ケース毎の計 算值すべてを, 低位発熱量別に求めた発電端熱効率で ある。一見してわかるように，10\%以下しか利用して いなかった従来施設の熱効率が，上記提案策を講じる ことによって大幅に上昇できたとしても，20\%がぎり ぎり限度である。新鋭火力発電所と対比させること自 身無理なことは承知しているが，半分以下しか利用さ れない現実を，重視しないわ忊にはゆかない。焼却処 理方式の実状を見極め, これ以上のごみ潜在エネルギ 一を利用するためには，焼却方式のシステムを変更す るか，焼却方式以外の設備を導入しなければ好転しな いであろらことを理解できたとして，本節の結論とす る。

\section{3. 熱分解方式によるごみ発電}

2.5 項に打いて蒸気タービン内の膨張排気を水冷却 によって, 可能極限まで下げることを発電出力增強策
としたが，タービン入口条件については，2 節全稿を 通してノータッチに終った。それは前にものべたが， 蒸気温度を高くとれないためであり, 燃焼排ガス中に 腐食成分が含まれていることに起因している。气れ 故, 排ガス中の $\mathrm{HCl}$ ガスその他を除去しない限り, 過熱器管を消耗品扱いにするしか方法はなく, $300^{\circ} \mathrm{C}$ の壁を越すことはできないであろう。(備考：過熱器管 金属表面侸自然成尘する酸化被膜が高温腐食を防ぐとの欧州 を中心にした説もある。また，材質面でカバーしょうとする 考方方もできるが，いずれも慎重な実証テストを行ら必要が ある。この腐食成分を十分に除くには，湿式洗浄する 方法しかなく, 熱回収方式は, 熱分解法によらざるを 得ない。熱分解法には多くのプロセスが発表されてい る。大別して, ガス化方式と油化方式に, ガス化方式 には熱分解十廃熱ボイラー式と熱分解十ガス燃燒ボイ ラー式とがある。前者は焼却方式と同㥞次, 腐食性物質 を含んだ燃焼排ガスが廃熱ボイラーを通過するので， 高温蒸気は望めない。後者は熱分解可燃性ガスを洗浄 してからガス燃焼ボイラーによって熱回収をするた め, 高エンタルピ蒸気条件の選定が可能になる。これ ら両者と燒却方式とのエネルギー経済比較は, 本協会 誌55年 4 月号4) (636号) 飞揭載しているので詳述しな い。対象とした熱分解方式の概略は, 図11のブロック シートのものであって, 70 ata $\times 450^{\circ} \mathrm{C}$ の蒸気条件で, 発電端熱効率 $\div 20 \%$ を得ている。この試算値を本稿の 設定条件にスライドすると約 $22 \%$ に達し, 焼却法より 優位にあることを裏付けた。ただし，熱分解法は消費 電力の大きい破砕機を持ち，プロセスによっては，化 石然料を熱分解熱源使用するため, 所内消費エネル ギーを除いた真のエネルギー量の差は縮るる。

\section{4. 複合システム熱利用方式}

ごみを燒却あるいは熱分解によって蒸気タービンを 駆動させる方式で，前節以上にごみの潜在エネルギー を取り出すことはきわめて困難である。ごみの熱利用 率は $20 \%$ 前後がリミットで，ランキンサイクルの久点 ともい党る。

欧州では清掃事業開始当初より，ごみを燃料として 扱い，処理と熱利用を綜合的汇計画する風習が根付い て祘り，火力発電所と併合した焼却施設が多い。合理 的な発想である。わが国衹いいて，欧州式システムを 踏襲しなかった理由は, 機械炉勃興当初のごみ質が悪 く，熱回収に適さなかったこともあるが，行政管轄の 相違や，建設地域の問題など表面上の理由として揭げ られる。しかし，安い価格の原油を主燃料重油 火力が発電事業の主流を占めて, 固体然料のごみと, 


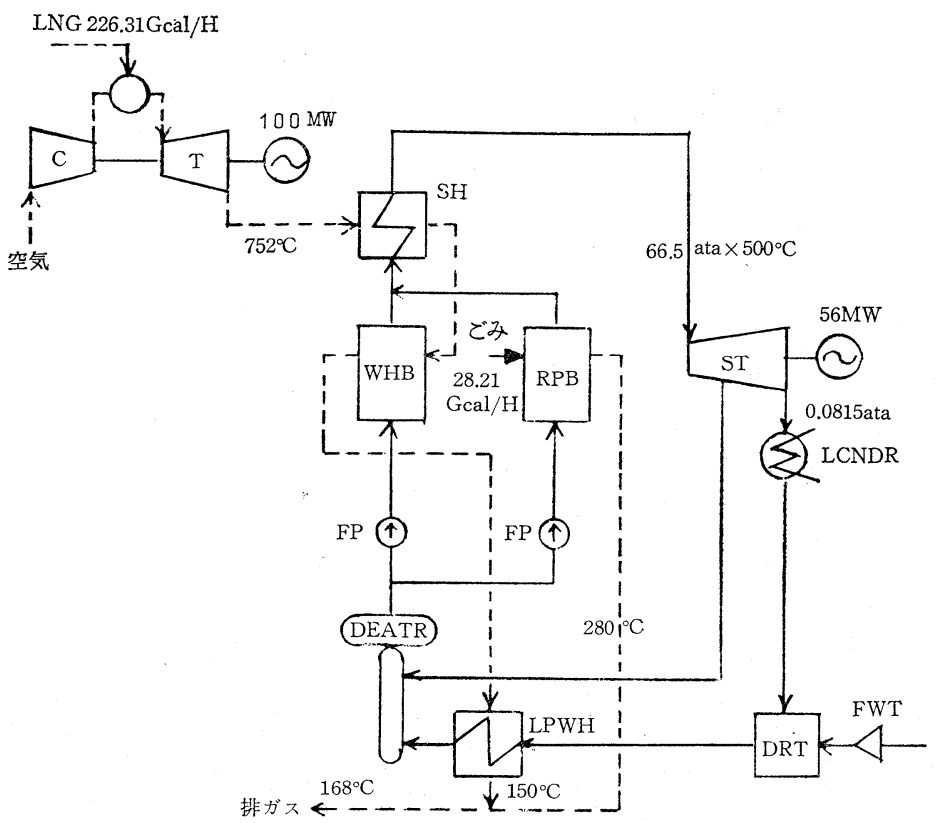

図 12 複合システムごみ焼却方式

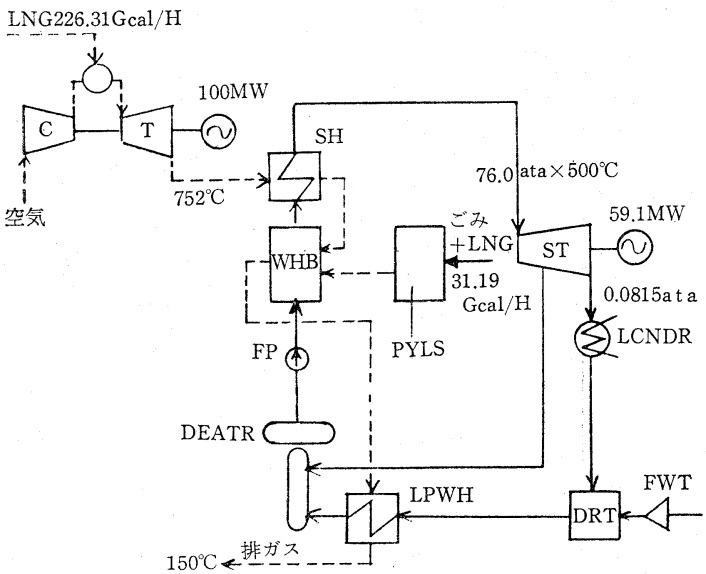

図 13 複合システム熱分解 (A) 方式

構造上の異和感が一番大きな理由ではなかったかと思 っている。原油高騰期を迎光, 重油専焼火力の王座が 危くなりつつある今日，相互利用によってエネルギー バランスを計った複合施設建設のチャンスである。火 力発電所とごみ㝸却とのカップルについての紹介記 事 ${ }^{5)}$ は多いが，エネルギーバランスを試算した報文は 見かけない。本誌でとりあげる予定であったが，紙面 の都合上またの機会にしたい。ここでは別の複合シス テム例 3 件について考察する。

4.1 ガスタービンとの複合システム
現在実用化されているガスタービンサイクルで，蒸 気タービン重油火力以上の熱効率を得るためには，ガ スタービン入ロガス温度の高温化と, 圧縮機圧力比を 15以上にとることが開発重要項目になっている。両者 とも官民共同の研究を進められていて, 近い将来実現 されるようになると思われる。完成の暁には，入口ガ ス温度 $=1,200 \sim 1,600^{\circ} \mathrm{C}$, 開放峃純ガスタービンの場 合, 圧縮機圧力比 $=30 \sim 60$, 熱効率 $=38 \sim 45 \%$, 開 放再生サイクルガスタービンでは, 圧縮機圧力比 $=8$ 〜20を用いて，熱効率＝43～50\%を得るよらになると 


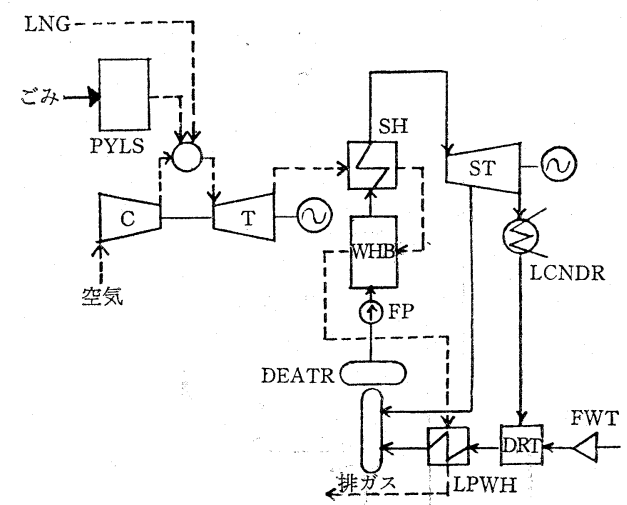

図 14 複合システム熱分解 (B) 方式

\section{$\mathrm{C}:$ 圧縮機}

$\mathrm{T}:$ ガスタービン

$\mathrm{SH}:$ 過熱器

$\mathrm{ST}:$ 蒸気タービン

WHB : 廃熱ボイラー

RPB : 焼却炉ボイラー

PYLS : 熱分解炬

DEATR : 脱気器
いわれている。ガスタービンが高温化されれば，当然 出口温度も高く, 顕熱回収が行われる。その手段とし て，ガスタービンサイクルにランキンサイクル蒸気タ ービンを組合せる複合サイクルの必要性が生じる。ュ ミュニティエネルギーシステム研究会の試算による

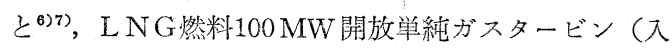
口温度 $=1,500^{\circ} \mathrm{C}$, 圧縮比 $=15 ）$ 之排ガス顕熱回収, 蒸気タービン複合サイクルプラントの場合, 蒸気ター ビン出力 $=45.3 \mathrm{MW}$, 発電熱効率= $53.3 \%$ を得てい る。また，同じ条件で開放再生ガスタービンと蒸気タ ービンの複合サイクルでは, 蒸気タービン出力 $=14.8$ MW，発電熱効率=53.2\%でめった。らなみに，この 両者のランキンサイクルのみの発電熱效率を計算して みると， $26 \%$ 及び $13.2 \%$ にった。

蒸気タービンとの複合サイクルが考光られるのであ れば,ごみ処理熱の受入れも思考されて不思議はな い。コミュニティエネルギーシステムの経済性が真剣 飞論議される最近, 都市単位のエネルギー需給及び環 境保全が技術上の重要開発テーマにランクづけされ る。ガスタービンとごみ処理との併合複合システムに は3つの形式が考光られる。図12，13，14にその概略 熱平衡フローシートを示した。図12はごみ焼却方式と の併合案である。最大の特徴はごみ烸却用廃熱ボイラ 一からは飽和蒸気の発生にとどめ, ガスタービン排ガ スで過熱させることであって, ごみ焼却方式の最大ネ ックであった蒸気温度の高温化が可能になることであ る。前述の複合サイクルの開放単純サイクルの設定諸 元と若干相違するが，同様な計算をごみ焼却熱回収を 加光て行ってみると, 綜合発電效率は $52.7 \%$ と大差な いが，蒸気タービンだけの效率は $26 \%$ に詨して $28.3 \%$ に上昇した。図13路よび14はごみの熱分解方式を組合

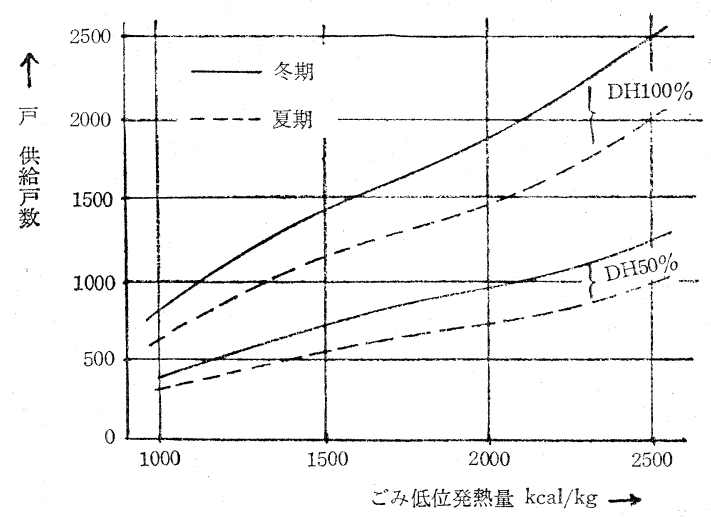

図 16 暖冷房供給能力 
表 3 ガスタービン複合システム主要数値

\begin{tabular}{|c|c|c|c|c|c|c|c|c|}
\hline & $\begin{array}{l}\mathrm{G} / \mathrm{T} \text { 入熱 } \\
\mathrm{G} \mathrm{cal} / \mathrm{H}\end{array}$ & $\begin{array}{c}\mathrm{G} / \mathrm{T} \text { 出口 } \\
\text { 温 }{ }^{\circ}{ }^{\circ}{ }^{\text {度 }} \\
{ }^{2}\end{array}$ & $\begin{array}{c}\mathrm{G} / \mathrm{T} \text { 出力 } \\
\mathrm{MW}\end{array}$ & $\begin{array}{l}\text { ごみ入熱 } \\
\mathrm{Gcal} / \mathrm{H}\end{array}$ & $\begin{array}{c}\mathrm{S} / \mathrm{T} \text { 入口 } \\
\text { 蒸気条件 } \\
\text { ata } /{ }^{\circ} \mathrm{C}\end{array}$ & $\begin{array}{c}\mathrm{S} / \mathrm{T} \text { 出力 } \\
\mathrm{MW}\end{array}$ & $\begin{array}{l}\text { 総合 } \\
\text { 熱效率 } \\
\% \\
\%\end{array}$ & $\begin{array}{c}\text { 蒸気サイク } \\
\text { 几熱勃率 } \\
\% \\
\%\end{array}$ \\
\hline 開放単純 $G / T$ & [ 234.33 & 775 & 100 & - & $100 / 538$ & 45.3 & 53.33 & 26 \\
\hline 開放再生 G/T & $\quad 185.49$ & 523 & 100 & - & $74.6 / 473$ & 14.8 & 53.22 & 13.33 \\
\hline $\begin{array}{l}\text { 開放単純 } \mathrm{G} / \mathrm{T} \\
+ \text { ごみ焼却 }\end{array}$ & 226.31 & 752 & 100 & 28.21 & $66.5 / 500$ & 56 & 52.71 & 28.34 \\
\hline $\begin{array}{l}\text { 開放単純 } \mathrm{G} / \mathrm{T} \\
\text { 土熱分解 }(\mathrm{A}) \\
\end{array}$ & 226.31 & 752 & 100 & 31.185 & $76 / 500$ & 59.1 & 53.14 & 29.4 \\
\hline
\end{tabular}

表 4 主 要計 算 值

\begin{tabular}{|c|c|c|c|c|c|c|c|c|}
\hline & ご み低 & 位発熱量 & & $\mathrm{kcal} / \mathrm{kg}$ & 1,000 & 1,500 & 2,000 & 2,500 \\
\hline \multirow{3}{*}{ D H負荷 } & \multirow{3}{*}{$0 \%\left\{\begin{array}{l}\text { 発 } \mathrm{D} \\
0\end{array}\right.$} & \multirow{3}{*}{\begin{tabular}{c}
\multicolumn{2}{c}{ 電 } \\
$\mathrm{H}$ \\
合 負 \\
熱 効
\end{tabular}} & \multirow{3}{*}{$\begin{array}{l}\text { 量 } \\
\text { 荷 } \\
\text { 率 }\end{array}$} & \multirow{3}{*}{$\begin{array}{c}\mathrm{kW} \\
\mathrm{Gcal} / \mathrm{H} \\
\%\end{array}$} & \multirow{3}{*}{$\begin{array}{r}2,600 \\
0 \\
15.06\end{array}$} & \multirow{3}{*}{$\begin{array}{r}4,000 \\
0 \\
17.10\end{array}$} & \multirow{3}{*}{$\begin{array}{r}5,000 \\
0 \\
17.64\end{array}$} & \multirow{3}{*}{$\begin{array}{r}6,400 \\
0 \\
18.52\end{array}$} \\
\hline & & & & & & & & \\
\hline & & & & & & & & \\
\hline \multirow{3}{*}{ D H負荷 } & \multirow{3}{*}{$50 \%\{$} & \multirow{3}{*}{\begin{tabular}{c}
\multicolumn{2}{c}{ 電 } \\
$\stackrel{\text { 負 }}{\text { 合 熱 効 }}$
\end{tabular}} & 量 & \multirow{3}{*}{$\begin{array}{c}\mathrm{kW} \\
\mathrm{Gcal} / \mathrm{H} \\
\%\end{array}$} & \multirow{3}{*}{$\begin{array}{r}1,800 \\
2.4 \\
27.35 \\
\end{array}$} & \multirow{3}{*}{$\begin{array}{r}2,800 \\
4.23 \\
32.46\end{array}$} & \multirow{3}{*}{$\begin{array}{r}3,500 \\
5.57 \\
34.07\end{array}$} & \multirow{3}{*}{$\begin{array}{r}4,500 \\
7.41 \\
35.95\end{array}$} \\
\hline & & & 荷 & & & & & \\
\hline & & & 率 & & & & & \\
\hline \multirow{3}{*}{ DH負荷 } & \multirow{3}{*}{$100 \%\{$} & \multirow{3}{*}{ 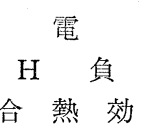 } & 量 & \multirow{3}{*}{$\begin{array}{c}\mathrm{kW} \\
\mathrm{Gcal} / \mathrm{H} \\
\%\end{array}$} & \multirow{3}{*}{$\begin{array}{r}1,300 \\
4.8 \\
41.18\end{array}$} & \multirow{3}{*}{$\begin{array}{r}2,000 \\
8.46 \\
49.62\end{array}$} & 2,500 & \multirow{3}{*}{$\begin{array}{l}3,000 \\
14.82 \\
55.13\end{array}$} \\
\hline & & & 荷 & & & & 11.15 & \\
\hline & & & 率 & & & & 52.36 & \\
\hline
\end{tabular}

D H：暖冷房負荷

せた方法である。図13は熱分解炉から発生した可然少 スをガスタービン廃熱ボイラーの燃焼室で然焼させた フローであり, 図12の焼却方式より単純化されてい る。熱分解方式は発生ガス洗浄タイプしかこの複合サ イクルに応用でさないのは, 高温腐食のリスクを考兄 てのことである。ガス洗浄を行っても，腐食成分はゼ ロになるわ汗ではない。 $\mathrm{HCl}=10 〜 20 \mathrm{ppm}$ ，ダスト= $0.1 \mathrm{~g} / \mathrm{Nm}^{3}$, 過剩 $\mathrm{O}_{2}$ 中の燃焼となると腐食三成分が 僅かといえども残存し, しかも $1,200 \sim 1,500^{\circ} \mathrm{C}$ の高温 燃焼を強いられる熱分解ガスガスタービン然焼方式 （図14）は，香だ研究の余地を残している。また，単純 サイクルに比べ再生サイクルは, 排ガスで圧縮空気加 熱を行らのでタービン排ガス温度が低く, 蒸気タービ ン用蒸気温度を高く採ることができないので，ごみ処 理と併合するメリットは薄くなる。表 3 にガスタービ ン複合システムの纆めを記した。

\section{2 熱併給方式}

ごみの持つエネルギーを電力に代える利用率は他の 然料の補助なしで20\%程度しか期待できないことはす でにのベた。効率の悪い電力の発生は所内消費分だけ とし蒸気を直接利用する方法か, 高温水利用に思考を
切換えるのも重要な熱利用方法である。ただこれらの 方法は需給のバランス上地域的あるいは用途的に限定 され如何なる地域に和いても利用できる方法とはい光 ない。

\section{A. 地域暖冷房熱供給}

蒸気タービンサイクルから暖冷房用熱源を供給する 方法は, 背圧式タービンを用いて背気により暖冷房用 熱交換器を加熱するす法と図15のように抽気復水タ一 ビンの抽気を加熱源にする方法とがある。試算には他 の方式と比較する目的があるので後者の方式をとるこ とにした。まず所内電力は自家供給き原則とする。ご みトン当りの消費電力を $70 \mathrm{kWh} / \mathrm{t}$ ーごみとすると， $70 \times 300 / 24 \times 1.2=1,050 \mathrm{kWh}(1.2$ はマージン率) こ れを発電最小限容量とする。他の余剩蒸気はタービン の抽気よりとり出し, 暖冷房用熱交換器で高温水を発 生させる。タービンは最大蒸気吞込量の10\%を最小流 量とし，その他すべての蒸気を暖冷房負荷 (DH負荷) に供給する。この場合をD H 負荷 $100 \%$ とし, DH負 荷用抽気なしですべてタービンへ供給するケースを負 荷 0 とする。この仮定のもとに計算して次の結果を得 た。 
表 5 主 要計 算 值

\begin{tabular}{|c|c|c|c|c|c|}
\hline ごみ低位 発熱量 & $\mathrm{kcal} / \mathrm{kg}$ & 1,000 & 1,500 & 2,000 & 2,500 \\
\hline 造水用蒸気量 & $\mathrm{kg} / \mathrm{H}$ & 12,660 & 22,260 & 29,300 & 38,920 \\
\hline 造 水 量 & $\mathrm{T} /$ 日 & 3,650 & 6,410 & 8,450 & 11,210 \\
\hline 換 算 給 水 人 口 & 人/日 & 9,600 & 16,860 & 22,230 & 29,500 \\
\hline 消 費 電 力 量 & $\mathrm{kWh}$ & 710 & 830 & 980 & 1,150 \\
\hline プラント全体消費電力量 & 11 & 1,610 & 1,780 & 1,980 & 2,200 \\
\hline 発電 量 & 11 & 1,630 & 2,550 & 3,260 & 4,230 \\
\hline 熱利 用 & $\%$ & 55.2 & 67.1 & 71.05 & 75.40 \\
\hline
\end{tabular}

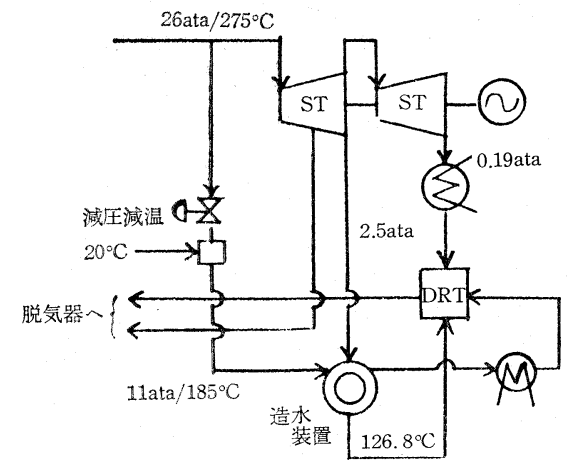

図 17 海水淡水化熱供給フロ一

燒却炉基準条件

（焼 却炉）焼却量：12.5 T/H $\mathrm{Hl}=1,000 \sim 2,500 \mathrm{kcal} / \mathrm{kg}$

排ガス温度 : $220^{\circ} \mathrm{C}$ 燃焼室出口冷却なし。 (タービン) 形式：抽気復水タービン

入口蒸気条件 : $26 \mathrm{ata} / 275^{\circ} \mathrm{C}$

復水器圧力 : $0.19 \mathrm{ata}$

定格負荷 : $6,800 \mathrm{~kW}$

計画蒸気タービン出力が大きすぎるため（抽気 $=0$ \%をベースに設計したタービン） $100 \%$ 抽気しても所 内の電力をまかなら以上の出力となった。売電と熱供 給両者を都合よくふり分けるようなことはできないの で, 小容量出力のタービンを設けるか, 背圧タービン 式を採用する方が経済的であるし，実質熱利用効率も 上るであろら。計算值は経済性に関係なく求められ， 発生電力と DH負荷との合計熱量は入熱に対し $50 \%$ 前 後の効率が得られる。ただし，暖冷房は季節的に利用 制限があり，年間を通じて高効率の操業をするわけに はいかない。利用季の谷間を如何に埋めるかが課題で ある。それと, ごみ質の変動に対して契約熱供給ノル マを賄えない場合を考えて, 補助熱源発生装置を絶対 に設ける必要がある。1 日の時間的負荷パターンに対
して，アキュムレータの設置が効果的であろう。表 4 の供給可能 DH 負荷は, $2.4 \sim 14.82 \mathrm{Gcal} / \mathrm{H}$ に及ぶ が，これを供給戸数に画いたのが，図16である。1户 当りの最大熱負荷で表わし暖冷房とも給湯負荷を含ん でいる。

B. 海水淡水化

前項 $\mathrm{A}$ 同様タービン抽気熱利用の方式として海水の 淡水化が揭げられる。方式自身はすでに一般化され, 研究報告 ${ }^{899)}$ も多数発表されているので詳述は避ける が，暖冷房方式以上に地域制限を受け現実性に之し い。既発表の文献によれば，然料を用いる方式の造水

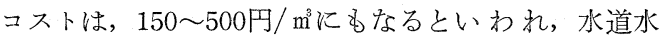
単価とかけはなれた高額になることから, 飲料水の得 難い特殊地域に限定されていた。化石燃料の価格が上 り, 水道水価格の大部分を占める電気代も值上げされ た今日，燃料と電気料金がゼ口（実際にはごみ焼却運 転経費を加算しなければならない）のごみ焼却-発電一 造水システムをもら一度見直す意義があるものとして 取上げた。近々, 水道水単洒は值上げされると思う。 值上げ後いくらの単価になるかわからないが, 現単価 は筆者の住む市で次のランク付け価格が適用されてい る。

$$
\begin{array}{rr}
11 \sim 25 \mathrm{~m}^{3} & 62 \text { 円 } \\
26 \sim 50 \mathrm{~m}^{3} & 86 \text { 円 } \\
51 \sim 100 \mathrm{~m}^{3} & 108 \text { 円 } \\
101 \sim 500 \mathrm{~m}^{3} & 120 \text { 円 } \\
501 \sim \mathrm{m}^{3} & 132 \text { 円 }
\end{array}
$$

造水コストがこれら上水道単価より高額になるよう なら，高くなる要因として薬品等製造する際消費する 別のエネルギーが使われていることになるので，いく ら然料代がゼロであってもその計画は，特定の場合を 除き実施すべきではない。海水淡水化熱併給方式の概 略フローを図17亿示し, 概算結果を次にのべ表 5 に示 于े。 
表 6 全国下水道処理施設消費エネルギー予想

\begin{tabular}{|c|c|c|c|c|c|}
\hline 項 & 目 & 位 & 昭和 55 年 & 昭和60年 & 備 \\
\hline 人 & 口 & 人 & $115 \times 10^{6}$ & $120.5 \times 10^{6}$ & \\
\hline 対総人口比 & & $\%$ & 99.1 & 99.1 & \\
\hline 普 及 & & $\%$ & 26.85 & 56.4 & \\
\hline 処理区域人! & & 人 & $30.6 \times 10^{6}$ & $67.35 \times 10^{6}$ & \\
\hline 下 水 & 量 & $\mathrm{m}^{3} /$ 日 & $15.3 \times 10^{6}$ & $33.7 \times 10^{6}$ & $500 \ell /$ 人・日 \\
\hline 消費電力 & 量 & $\mathrm{MW} /$ 日 & 3,100 & 6,700 & $0.2 \mathrm{kWh} / \mathrm{m}^{3}$ 一下水 (焼却まで) \\
\hline 消費重油 & & K L/日 & 1,500 & 3,300 & $\begin{array}{l}\mathrm{SS}=250 \rightarrow 30 \mathrm{ppm}, \text { 污泥水分 }=75 \%, \\
100 \mathrm{~kg} / \mathrm{t}-\text { ケーキ }\end{array}$ \\
\hline 換算重油 & 量 & K L/日 & 710 & 1,540 & 発電熱効率 $=41.5 \% \mathrm{H} \ell=10,000 \mathrm{kcal} / \mathrm{kg}$ \\
\hline 重油量合言 & 計 & KL/日 & 2,210 & 4,840 & \\
\hline 換算電力 & 量 & MW/日 & 6,500 & 14,310 & \\
\hline 電力量合言 & 計 & MW/日 & 9,600 & 21,010 & \\
\hline
\end{tabular}

注）1. 換算重油量とは，消費電力量を重油火力発雷所で使用する重油に換算した值

2. 換算電力量とは, 消費重油量を重油火力発電所に送り発電したと仮定した電力量

3. 下水処理による発生污泥はすべて専用燒却炉で焼却するるのとする。

\section{設定条件}

造水設備方式 : 多段フラッシュ法

加熱蒸気: タービン抽気, 2.5 ata

エゼクタ蒸気：11 ata 使用量 $800 \mathrm{~kg} / \mathrm{H}$

造 水 比: 12

タービン設定条件は前 $\mathrm{B}$ 項同様タービン排気の最小 流量の夕通し, 所内所要量以外の大部分の 2.5 ata 抽 気を造水用に使用する場合の発電量拉よび造水量であ る。造水設備, 発電設備とも $\mathrm{Hl}=2,500 \mathrm{kcal} / \mathrm{kg}$ の ときの設計なので，実際使用する $\mathrm{Hl}=1,500 \sim 2,000$ $\mathrm{kcal} / \mathrm{kg}$ では相当軽負荷の操業で, 口スが多く計算結 果より割引いた表5の見方をしなければならないが,プ ラント全体の消費電力を賄い,かつ, $\mathrm{Hl}=1,500 \mathrm{kcal} / \mathrm{kg}$ 以上の発熱量では余剩電力を生じる。表中の換算給水 人口とは, 造水量を $380 \ell /$ 日・人で割った值で参考値 である。ちなみに，最高值11,210 T/日 の水を重油を 用いて造水したと仮定すると, 造水に要したエネルギ 一の重油換算量は約 $87 \mathrm{k} \ell /$ 日に及ぶ。また, ごみの熱 利用率は55〜 75\%と今までの最高值を示した。

\section{5. 下水・ごみ竍合処理施設}

送電口スを防ぐ省エネルギー策として, 超高圧化, 逆の発想からなる小規模地域発電など，パワープラン トの従来方式からの脱皮について研究, 論議されてい る。都市清掃行政汇出っては, 旧態依然としてマルチ 分散形が踏襲されていて，たまに集中化の計画もある がケーススタディにとどまっている。広域集中処理方 式が実現されれば, 物質的, 労力的のエネルギー節減 は計り知れない。特炕都市周辺の人口密集都市は市
境を接し，処理施設の建設用地や二次廃㟥物処分場の 確保もままなら妨のに，都市毎に処理施設を建設する 状沉にある。これらの都市群が，一部事務組合の形体 をとれば，大都市なみの処理規模も期待できよう。さ らに，ごみ処理にとぞをらず下水道終末処理場をも併 合すれば，相互の長所を伸し，短所を補う理想的処理 形体が誕生する。反面，行政管轄の違いから現実の具 体論になると拒否反応が予想され，一朝一夕に実現困 難と思われる。併合処理の特徽は, ごみ処理施設より 排出寸る廃水を下水処理施設へ, 下水处理からの污泥 をごみ焼却処理施設で堯却する相互処理のほか，エネ ルギーの受授があげられる。ごみ処理施設からの過剩 エネルギーを, 下水処理場で消費する, 理想的体形が 構成される。この併合処理構想関しては, すでに 2 $\sim 3$ の研究論文 ${ }^{10)}$ が発表され，若干新規性に欠ける が，具体的併合施設を仮定して両処理施設のエネルギ 一バランスを試算し，本ごみエネルギー利用シリーズ の完稿とする。

先般，日本経済新聞社が緅めた「全国下水道調查 $\left.{ }^{11}\right\rfloor$ （アンケート件数194件，回答率 $62.4 \%$ ) に上ると, 各 自治体の下水道整備は，昭和60年にかけて大きく盛上 る見达みで, 公共下水道の涪か流域下水道の普及を中 心に環境整備の実態がクローズアップされている。回 答中注目される事項は, 電力, 石油の高騰による維持 管理経費の膨張をあげる件数が圧倒的に多かったこと と, 技術的には污泥処理の開発を期待する声の高かっ たことである。紙面によると，下水道の普及率(実績) は，昭和 55 年 3 月時点で $20 \sim 40 \%$ 多く，72件（全体 
表 7 自燃ごみカロリー予想

\begin{tabular}{|c|c|c|c|c|c|c|c|c|}
\hline 項 & & & & 位 & 水 & 污 泥 & ごみ & 混合ごみ \\
\hline 発 & 生 & & 量 & $\left(\mathrm{m}^{3}\right) t /$ 日 & $\left(180 \times 10^{3}\right)$ & 158.4 & 540 & \\
\hline 発 & 熱 & & 量 & & & & & \\
\hline 㨁 & 接 & 勞 & 燒 & $\mathrm{kcal} / \mathrm{kg}$ & & 300 & 1,200 & 1,000 \\
\hline 乾 & 燥 & 燃 & 焼 & $\mathrm{kcal} / \mathrm{kg}$ & & $2,460($ 水分 $=15 \%)$ & 870 & 1,000 \\
\hline 燒 & 却 & & 量 & $\mathrm{t} / \mathrm{H}$ & & 1.94(乾燥污泥) & 22.5 & 24.44 \\
\hline
\end{tabular}

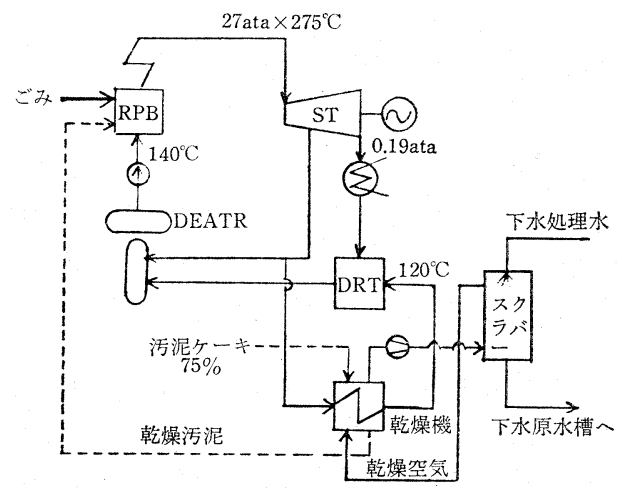

図 18 下水-ごみ併合処理フロー

の37. 1\%), 続いて $0 \sim 20 \%=56$ 件 $(28.9 \%)$, 要する に普及率 $0 \sim 40 \%$ が過半数を占めて，整備の遅れを裹 づけいる。昭和 60 年 3 月予想になると，件数の多い 順に，60〜80\%=38件 $(19.6 \%) ， 50 \sim 60 \%$ 及び $20 \sim$ $40 \%$ 同件数 $=32$ 件（16.5\%）とつづき，普及率 $100 \%$ も14件（7.2\%）に及んでいる。これらの件数から計 算すると，全体平均普及率は，昭和 55 年 $=26.8 \%$, 昭 和 60 年 $=56.4 \%$ になった。 5 年後に現在の倍以上普及 されるかどうか，多分に希望的観測が含まれているで あろらが，もし現実となった場合，消費形である下水 処理施設の費すエネルギー量は莫大な数值になるもの と予想できる。日本全国同率の普及率および同形式扰 理施設であると仮定して計算すると，表 6 のようにな る。

上表の通りであり, 将来もし 3 次処理まで行わなけ ればならないような場合には，電力は約 2 倍消費さ れ, 大型火力発電所 1 力所を下水処理専用に運転させ る程の消費電力量になる。

このように多大のエネルギーを消費する下水処理施 設に，ごみ焼却処理施設を合体併設した場合に，どの よらなエネルギーバランスになるでめろうか。モデル 都市を設定して試算を行った。

河川流域都市人口 450,000人
表 8 下水一ごみ併合処理施設エネルギーバランス

\begin{tabular}{|c|c|c|c|c|}
\hline ごみ低位発熱量 & $\mathrm{kcal} / \mathrm{kg}$ & 1,000 & 1,500 & 2,000 \\
\hline 混合ごみ発熱量 & " & 1,120 & 1,580 & 2,040 \\
\hline 焼 却 量 & $\mathrm{kg} / \mathrm{H}$ & 24,440 & 24,440 & 24,440 \\
\hline ボイラー蒸発量 & " & 33,000 & 50,700 & 66,100 \\
\hline タービン入口蒸気量 & 量 $"$ & 27,700 & 47,300 & 66,100 \\
\hline 発電端出力 & $\mathrm{kWh}$ & 3,800 & 6,900 & 9,800 \\
\hline 所内消費電力 & " & 2,300 & 2,400 & 2,500 \\
\hline 余 剩 電力量 & " & 1,500 & 4,500 & 7,300 \\
\hline 熱利用効率 & $\%$ & 35.9 & 32 & 30.6 \\
\hline
\end{tabular}

$\begin{array}{lc}\text { 下水道普及率 } & 80 \% \\ \text { 活泥脱水率 } & 75 \% \\ \text { 污泥低位発熱量 } & 300 \mathrm{kcal} / \mathrm{kg} \\ \text { ごみ特掃率 } & 100 \% \\ \text { ごみ発生量 } & 1.2 \mathrm{~kg} / \text { 人・日 } \\ \text { ごみ低位発熱量 } & 1,000 \sim 2,000 \mathrm{kcal} / \mathrm{kg}\end{array}$

設定条件に対しごみおよび污泥の発生量は表 7 に示 す通りになる。低カロリーの污泥をごみに混合して自 然するかどらか，予わ予想して䋇かければならな い。污泥を混合したごみ（以下混合ごみと呼ぶ）の自 然カロリーを $1,000 \mathrm{kcal} / \mathrm{kg}$ とすれば, 混合前のごみ のカロリーは約 $1,200 \mathrm{kcal} / \mathrm{kg}$ 以上あればよい。污泥 を乾燥させて混合した場合には，約 $870 \mathrm{kcal} / \mathrm{kg}$ とな る。 $75 \%$ 水分の污泥をごみとまんべんなく混合させる ことは困難である。乾燥污泥は炉内への噴霧燃焼が可 能であり, 操作上の難易から乾燥污泥然燒式とした。 污泥乾燥方式は, 抽気蒸気を熱源とし, スクラバーを 介して空気を循環させる方式とした。スクラバーのス プレ一水は下水の処理水を用い, スクラバー排水は下 水原水へ還流させる。全体の処理フローは図18を参照 されたい。

この規模の下水処理場を単独で運営する時のエネル ギ一量は, 電力消費量 $=22,900 \mathrm{kWh} /$ 日, 重 油消費 量=16. $2 \mathrm{~K} \mathrm{~L} /$ 日 となり，ごみと併合処理することに よって，この消費分はまるまる節約することができ 
る。

表8に見られるように, 都市から排出するごみと下 水のエネルギーバランスは, ごみ $=100 \%$, 下水 $=80 \%$ の収集率で, ごみの出力超過になった。ごみの排出量 が1. $0 \mathrm{~kg} /$ 人・日であっても成立する。発熱量的には， ごみの $\mathrm{Hl}=1,000 \mathrm{kcal} / \mathrm{kg}$ と低カロリーであってもバ ランスはとれる。現時点に特けるごみの発熱量は平均 $1,500 \mathrm{kcal} / \mathrm{kg}$ 程度と思われるので, 将来下水処理が 三次処理まで実施してもェネルギーバランスは十分成 立する。熱利用効率は，30\%台にとどまったが，シス テム的に変更せず単に同一系内の他の施設の消費電力 を肩代りしただけで，10１5％（表2 参照）上昇でき る点に注視する必要がある。熱利用はエネルギー発生 側と消費側との組合せの妙により効果を発揮する。

\section{6.おちりに}

試算結果から，焼却炉形式の諸条件を変えることに よって, 現有施設の 2 倍以上の熱利用効率を期待する ことができることがわかった。技術的汇は既知のこと ばかりで，実行に当って新しく開発しなければならな いことはない。結果はどうあれ，積極的にごみの熱量 をひき出そうとする姿勢の方が重要である。また，熱 利用の方法は，電気エネルギー転換だけでなく，地域 特性を生かし, 蒸気や温水の用途開発が有効であり熱 利用効率はさらにあがる。

省エネルギーとは，在来消費エネルギー量を節約す ることに相違ないが，熱機関の効率を上げてょり多く のエネルギーを生み出すことでるあり, 取り出された エネルギーを上手に運用することも省エネルギー対策 である。単一設備に打ける効率の限界も別の用途や代 用するなどの応用によって，ま限界を越えることが できる。都市環境整備事業も単一処理施設管理の時代 から複合, 併合施設の時を迎え, 熱の有効利用に大き く前進することが期待される。
本稿は処理施設のエネルギー中心のシスラム検討に 終始したが，エネルギー利用量多寡批拥と共に，建設 費を試算し，原価償却を含めて結論を導く必要がある ことを追記する。

\section{文献}

1）八鴆昭一：「大型ごみ発電」環境技術， 9, №. 5

2）野飼 潔, 前嶋計造: 「葛飾清掃工場飞拈ける低 NOx 運転について」清掃技報第 4 号 東京都清 掃局

3) 平岡正勝, 武田信夫, 堀喜久男他「ごみ焼却炉の 自動燃燒制御と NOx 運転について」環境技術,

\section{8, No. 12}

4）可燃性廃棄物委員会：「省エネルギーごみ処理に ついての考察」燃料協会誌，59,636

5）ごみ焼却発電調查研究委員会：「中小都市ごみ焼 却発電に関する調查研究報告書」(社)日本熱エネ

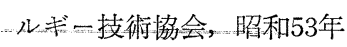

6) コミュニティ発電システム研 究会:「高熱効率コ ミュニティ発電システム調查研究報告書第 2 報」 (社)日本熱エネルギー技術協会, 昭和53年

7）コミュニティエネルギーシステム研究会：「コミ ュニテイエネルギーシステム調查研究報告書第 3 報」(財)省エネルギーセンター 昭和 54 年

8 ）省エネルギー・シティ部会廃熱グループ:「第 3 部, 廃熱, 廃棄物再利用を考慮したエネルギーと水の トータル・システム」(財)大阪科学技術センタ 一, 昭和 55 年

9）「沖綿本島海水淡水化計画調查報告書第 1 次」厚 生省水道環境部 昭和 54 年

10）平岡正勝:「都市ごみ・下水処理とエネルギー問 題」環境技術 9, No. 3

11）日経産業新聞「高揚期の下水道整備」昭和55年 5 月26日 


\title{
A New Study for Energy Recovery from Municipal Refuse Processing by Thermal Treatment
}

\author{
Mamoru YAMADA
}

(Mech. Enging. Divison, Kokushikan University)

SYNOPSIS : - We are now facing to the era of difficulty in recuring a necessary amount of petroleum in Japan and we must proceed the save-energy programs before the development of the alterrative energy. Concerning to the municipal refuse processing, it is possible to obtain the higher thermal efficiency by the improvement of operating conditions in the conventional power plant alone or the applications of the system with another heat utilization in addition to the power plant or the system combined with another energy using process. In this paper, several save-energy programs are studied through calculating thermal efficiency of these systems for various LHV (Lower Heat Values) of refuse. 